\title{
Material Recommendation System for Distance Learning Based on Fuzzy Logic
}

\author{
Beyza Esin Özseven ${ }^{1 *}$, Naim Çağman ${ }^{2}$ \\ ${ }^{1 *}$ Tokat Gaziosmanpaşa University, Institute of Graduate Studies, Department of Mathematics, Tokat, Turkey, (ORCID: 0000-0003-4888-8259), \\ beyza_esin@hotmail.com \\ ${ }^{2}$ Tokat Gaziosmanpaşa University, Faculty of Science and Letters, Department of Mathematics, Tokat, Turkey (ORCID: 0000-0003-3037-1868), \\ naim.cagman@gop.edu.tr
}

(First received 22 December 2021 and in final form 28 January 2022)

(DOI: 10.31590/ejosat.1061483)

ATIF/REFERENCE: Özseven, B.E. \& Çăgman, N., Xxxx, X. (2022). Material Recommendation System for Distance Learning Based on Fuzzy Logic. European Journal of Science and Technology, (33), 311-317.

\begin{abstract}
A course material is the most important support material for the student throughout the learning process. Especially in distance learning, course materials gain even more importance. Materials to be presented in distance learning systems should be determined according to the student's readiness level and learning style. The main goal is how to best realize learning. In this study, based on the fuzzy logic a material recommendation system is modeled for distance learning systems. In the proposed model, in addition to readiness and learning style, material difficulty level and material type are also used. After the fuzzy rule base created, it determined whether each material is suitable for students.
\end{abstract}

Keywords: Distance learning, readiness, material recommendation, learning style, fuzzy logic.

\section{Uzaktan Öğrenme İçin Bulanık Mantık Tabanlı Materyal Öneri Sistemi}

$\ddot{O} \mathbf{z}$

Bir ders materyali öğrenme süreci boyunca öğrencinin en önemli destek materyalidir. Özellikle uzaktan öğrenmede ders materyalleri daha da fazla önem kazanmaktadır. Uzaktan öğrenme sistemlerinde sunulacak materyaller öğrencinin hazır bulunuşluk seviyesi ve öğrenme stiline göre belirlenmelidir. Temel amaç öğrenmenin en iyi nasıl gerçekleştirileceğidir. Bu çalışmada, uzaktan öğrenme sistemleri için bulanık mantık tabanlı bir materyal öneri sistemi modellenmiştir. Önerilen modelde, hazır bulunuşluk ve öğrenme stiline ek olarak materyal zorluk seviyesi ve materyal türü de kullanılmıştır. Oluşturulan bulanık kural taban sonrası her bir materyalin öğrenciler için uygun olup olmadı̆̆

Anahtar Kelimeler: Uzaktan öğretim, hazır bulunuşluk, materyal öneri, öğrenme stili, bulanık mantık.

\footnotetext{
* Corresponding Author: beyza esin@hotmail.com
} 


\section{Introduction}

Learning style is defined as cognitive, affective and physiological behaviors that are indicators of students' perception structure, interaction with the distance learning system and reactions (Bahar and Sülün 2011; Given 1996). The main goal of leraning style is how to best realize learning. Educators state that there are three different learning style approaches: self-awareness, curriculum design and application to teaching processes, and diagnostic perspective (Can 2011). In this study, since the model for distance learning has been created, the perspective of application to curriculum design and teaching processes has been brought to the fore. Kolb, McCarthy, Butler and some other researchers have adopted learning styles of this nature (Can 2011). The most well-known of these styles and the most widely used in the literature is the learning theory developed by Kolb (Cevher and Yildirım 2020). The theory focuses on both cognitive and affective dimensions, as well as emphasizing the importance of experiences in the learning process (Can 2011).

Both the education and the teaching process are carried out depending on past experiences. Lack of experience or previous knowledge of students will also cause problems in the next education-teaching processes. The subjects for the lessons follow each other and the previous subjects form the basis for a subject to be learned. For this reason, before starting a new topic, previous learning about the topic should be acquired and it should be checked whether this situation exists in individuals (Altun 2005; Yenilmez and Kakmac1 2008). With readiness, it is investigated whether the student has sufficient knowledge for the new subject to be learned. In short, readiness is whether the individual has the necessary prerequisites for the relevant learning activity (Arık 1995; Yenilmez and Kakmac1 2008).

Materials are used as supportive resources for students in both distance and face-to-face learning. The source to be used differs according to the teaching method used. The biggest difference that distinguishes distance learning from face-to-face education is that the course materials gain great importance because the education is carried out independently of space and time. Lecture notes, lecture video recordings, presentations and texts are important in distance learning, which is carried out asynchronously. The effectiveness of these materials is related to the effectiveness of the educator, and the educator should know their strengths and weaknesses. Especially developing web technologies have increased the interaction between course materials and students in distance learning systems.

One of the problems in distance learning systems is proposing suitable materials for students. Because, if permission is given, it may be necessary to choose among the materials shared by different educators on the same subject. It may be necessary to suggest material suitable for the student's learning style. Most studies in the literature are filter-based and based on student's past records. In this study, a student-centered approach is proposed to contribute to the literature. In the proposed approach, the course materials to be presented to the students are determined according to their learning style, readiness, material difficulty level and material type.

In the next section of the study, the situation in the literature was examined. In the third and fourth sections, basic information is given. The proposed model is given in the fifth section and the results and discussion are given in the last section.

\section{Related Works}

Learning style is important for the concepts learned to be permanent for a longer period. It also makes the concepts easier to understand. Learning styles are determined with the help of questionnaires in both online and offline applications. In the study, in which machine learning techniques and Kolb learning styles were used, a model was proposed to determine learning styles. In the proposed model, in addition to the scale information, age and gender data were also used, and classification was made with k-NN, C4.5 and Naive Bayes (Kartal et al. 2019). In the study examining the efficiency of Kolb learning styles, J48, BayesNet and Naïve Bayes and Random Forest classifiers were used. As a result, the highest success was obtained in the Random Forest (Menaka and Nandhini 2019). In the study, in which web usage mining was used for the determination of learning style in distance learning independently of the theories, the movements of the students on the websites were determined with the fuzzy classifier and higher success was achieved than the traditional methods (El Aissaoui et al. 2019). The results of the study, in which personalized and learner-specific learning strategies were developed according to Kolb's learning style for distance learning, showed that personalization in distance learning based on learning style significantly affects the academic success and satisfaction of students (Sanjabi and Montazer 2020). In the study conducted in 2021, different classifiers were used by reducing the scale sizes. While creating the data set, the time spent on audio files, concept maps, images, reading texts and simulations in the distance learning system was used. As a result, the highest success was obtained with the SVM classifier (Rasheed and Wahid 2021).

The studies described above and, in the literature, focused on two approaches to determine learning style. These are the student's behavior on the system and the questionnaires. Both approaches have strengths and weaknesses. The data obtained with the help of the questionnaires contain weaknesses such as the students' unawareness of their own preferences and the fact that the questionnaire creates boredom. These weaknesses are eliminated in the approach where the behavior of the student in the system is used. However, movements on the system also create weaknesses such as leaving the system open for a certain period and not using the system himself. In addition, theory-based studies focused on previous versions of Kolb learning style (KLSI) and were based on four learning styles.

Readiness, in addition to suggesting educational material to the student, also guides the educator in teaching the lesson. To achieve this, the educator needs to prepare a readiness test for each lesson topic. Although it seems to increase the workload of the educator, it can be used for many years as it will only be defined once.

When the studies on readiness in the literature are examined, the readiness of the primary school mathematics teacher students for the $2^{\text {nd }}$ grade high school mathematics lesson has been examined and it has been determined that the readiness level is quite low (Tuna and Kaçar 2005). In the study in which the relationship between preschool education and mathematics lesson was investigated, it was determined that the readiness for mathematics lesson of those who received preschool education was high (Unutkan 2007). Questionnaire data were used in the study in which the relationship between students' readiness levels and academic achievements for foreign language lessons was examined. According to the results of the study, it has been determined that the students' readiness levels and academic 
achievements vary according to gender and preparatory reading status. In addition, it was concluded that students with high readiness levels also have high academic achievement (Ünal and Özdemir 2008). The readiness of primary school students for the 7th grade mathematics lesson was investigated with a test including demographics, mathematics achievement, interest in mathematics and prerequisites, and suggestions were given to increase the level of readiness in mathematics (Yenilmez and Kakmac1 2008). Students' readiness was examined in terms of achievement test, semi-structured interview form and attitude scale and geographical concepts, and it was observed that the applied teaching techniques increased the learning level (Akengin and Süer 2013). According to the results of the study in which the readiness of mathematics teaching students about functions was examined, the participants in the study were insufficient in terms of functions (Erdoğan, Erdoğan, and Çelik 2012). In the study examining the readiness levels of pre-school teacher candidates to teach mathematics, it was determined that some participants saw mathematics as a way of life, while some participants saw daily words as a mathematical element (Inan 2014). In the study examining the effects of pre-lesson activities such as online tests on student readiness and performance, the answers of two groups of students to the preparatory questionnaires were compared (Fraley et al. 2015). In another study, the readiness of instructors in distance education was examined. In the study, definitions were made about the importance of readiness and its detection methods, as well as its sub-categories of cognitive, social and educational readiness (Koloğlu, Kantar, and Doğan 2016). In the study using distance learning perception scale and readiness scale, students' demographic data and answers to scales were used (Gökbulut 2021).

In the study, which aims to help students find the learning materials they need to read, the needs of the students were determined, and fuzzy matching was used to find the appropriate learning materials that would best meet the needs of each student. The criteria used are; student's personal characteristics, history of access to learning material, current interests and other student needs (Lu 2004). In the study, which aims to have students search for content using more than one keyword at the same time, the students' past records were analyzed and the relationship between students' learning behaviors, possible keywords and learning course content was determined (Liu and Shih 2007). In the study, in which certain features are defined as vectors, the learning rate for the features was defined, and the similarity rate between learner behaviors and materials was calculated (Salehi and Kmalabadi 2012). Collaborative filtering and sequential model mining are used in various studies used to recommend material. Collaborative filtering focuses on relationships between users with similar interests, while sequential model mining uses records of users' interactions with the system (Chen et al. 2014; Syed et al. 2017; Turnip, Nurjanah, and Kusumo 2017). In the study using fuzzy logic, student information, performance reports, study materials and user queries were used (Pandey and Singh 2015; Perumal, Sannasi, and Arputharaj 2019). In the study investigating the effectiveness of learning styles in material recommendation, Felder Silverman learning style, cooperative filtering, content-based filtering and grading were used and rating was determined as the best method (Trusthi and Nurjanah 2017).

Most studies on material recommendation in the literature use filtering (searching among materials) and student's past web traces. In this context, the inadequacy of student-centered studies that focus on the learning style of the student and use material prior knowledge is seen as a deficiency in the literature. In addition, studies involving Kolb's nine learning types are also limited.

\section{Learning Style}

KLSI is based on experiential learning theory (Can 2011; Göldağ 2011). KLSI is based on the learning style and problemsolving habits of students in their daily lives. There are four types of learning styles in this style (Aşkar and Akkoyunlu 1993; Çöpgeven and Firat 2019; Kolb 1985): Concrete Experience, Reflective Observation, Abstract Conceptualization, Active Experimentation. Here, it assumes that active experimentation is learned better by feeling, watching reflective observation, thinking about active experimentation, and doing abstract conceptualization. Learning style consists of a combination of these four styles. This combination determines the student's learning style (Aşkar and Akkoyunlu 1993; Can 2011). With KLSI 4.0, four learning types were transformed into nine learning types (Alice Y. Kolb 2013). The KLSI 4.0 dimensional diagram is given in Figure 1.

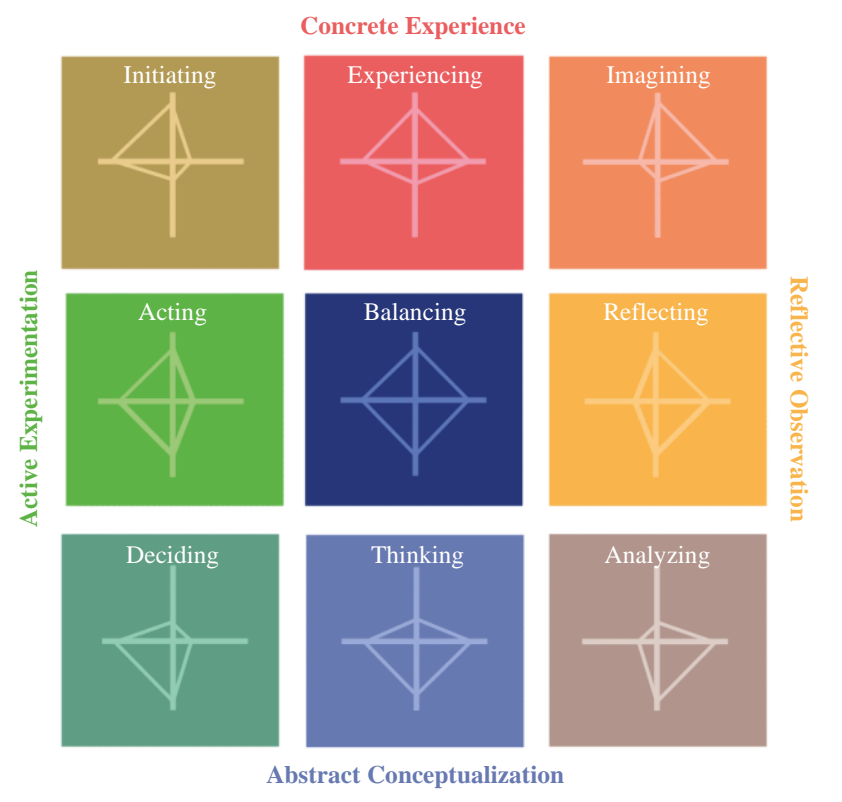

Figure 1. KLSI 4.0 (Anon 2017; A. Y. Kolb 2013)

Learning strengths and weakness for KLSI 4.0 are given in Table 1. 
Table 1. Learning strengths and weakness for KLSI 4.0 (Anon 2017)

\begin{tabular}{|c|c|c|}
\hline Style & Strengths & Weakness \\
\hline Initiating & $\begin{array}{l}\text { Dedicate yourself to your } \\
\text { goals } \\
\text { Searching for new } \\
\text { opportunities } \\
\text { Influencing and directing } \\
\text { others }\end{array}$ & $\begin{array}{l}\text { Controlling the urge to } \\
\text { act } \\
\text { Listening to the opinions } \\
\text { of others } \\
\text { Impatience }\end{array}$ \\
\hline Experiencing & $\begin{array}{l}\text { Building deep personal } \\
\text { relationships } \\
\text { Strong intuition focused on } \\
\text { thoughts and actions } \\
\text { Open to new experiences }\end{array}$ & $\begin{array}{l}\text { Understanding the } \\
\text { theory } \\
\text { Systematic planning } \\
\text { Evaluation }\end{array}$ \\
\hline Imagining & $\begin{array}{l}\text { Awareness of people's } \\
\text { feelings and values } \\
\text { Listening with an open mind } \\
\text { Visualizing the consequences } \\
\text { of uncertain situations }\end{array}$ & $\begin{array}{l}\text { To decide } \\
\text { Taking the lead } \\
\text { Act on time }\end{array}$ \\
\hline Reflecting & $\begin{array}{l}\text { Understanding others' point } \\
\text { of view } \\
\text { Seeing "What's going on" in } \\
\text { situations } \\
\text { Turning intuitions into clear } \\
\text { explanations } \\
\text { Data collection }\end{array}$ & $\begin{array}{l}\text { Initiating an action } \\
\text { Thinking too long } \\
\text { Raising your voice in a } \\
\text { group }\end{array}$ \\
\hline Analyzing & $\begin{array}{l}\text { Organizing information } \\
\text { To be logical and rational } \\
\text { Building conceptual models }\end{array}$ & $\begin{array}{l}\text { Risk taking } \\
\text { Socializing with others } \\
\text { Coping with structural } \\
\text { deficiency }\end{array}$ \\
\hline Thinking & $\begin{array}{l}\text { Analytics } \\
\text { Rational decision making } \\
\text { Analyzing quantitative data }\end{array}$ & $\begin{array}{l}\text { Working with people } \\
\text { Being open-minded } \\
\text { about ideas } \\
\text { Get lost in thought }\end{array}$ \\
\hline Deciding & $\begin{array}{l}\text { Problem solving } \\
\text { Evaluating ideas and } \\
\text { solutions } \\
\text { Setting goals } \\
\text { Making decisions }\end{array}$ & $\begin{array}{l}\text { Creative thinking } \\
\text { beyond the ordinary } \\
\text { Sensitivity to people's } \\
\text { feelings } \\
\text { Dealing with uncertainty }\end{array}$ \\
\hline Acting & $\begin{array}{l}\text { Combining technical } \\
\text { knowledge and personal } \\
\text { relationships } \\
\text { Focus on getting things done } \\
\text { Leading business teams }\end{array}$ & $\begin{array}{l}\text { Taking time to think } \\
\text { Solving the right } \\
\text { problem } \\
\text { Information gathering } \\
\text { and analysis }\end{array}$ \\
\hline Balancing & $\begin{array}{l}\text { Flexibility of movement in } \\
\text { the learning cycle } \\
\text { Ability to work with } \\
\text { different types of groups of } \\
\text { people } \\
\text { Creative intuitions }\end{array}$ & $\begin{array}{l}\text { Instability } \\
\text { To do everything you } \\
\text { can, but not to be an } \\
\text { expert in any of them } \\
\text { Constant commitment }\end{array}$ \\
\hline
\end{tabular}

To determine the learning style, it is planned to use KLSI 4.0, the demographic data of the student, the student emotion of each KLSI 4.0 question and the time to answer the question. KLSI 4.0 and the use of question-based emotion will contribute to the literature. In Figure 2, the suggested model for determining learning style is given.

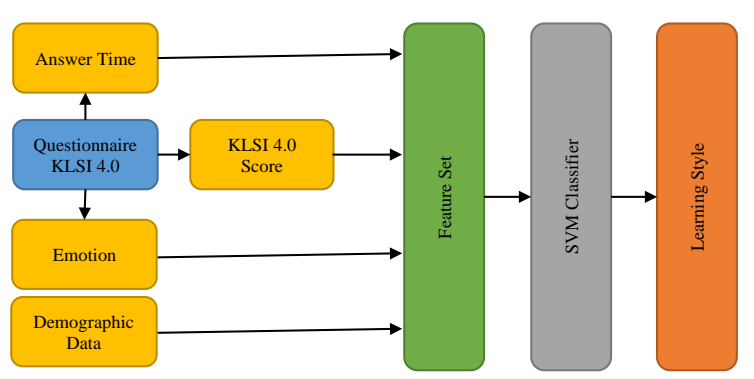

Figure 2. Learning style module
For the determination of the learning style given in Figure 2, the answer time of the student and the emotion at the time of answering, score value and demographic information for each question of the KLSI 4.0 questionnaire were taken as basis. The inconsistency of the answer time with the average time determined for the question will show that the answer given by the student may be incorrect. In this case, an average value that does not affect the overall score should be given for the relevant question. If this discrepancy occurs for more than $50 \%$ of the questions, it is recommended to repeat the test. In addition, the emotional state at the time of answering each question will also show the student's perspective on the related question. The expressions (IT-initiating, EX-experiencing, IM-imaging, RFreflecting, AL-analyzing, TH-thinking, DC-deciding, AC-acting, BL-balancing) were used for learning style.

\section{Readiness}

Readiness is whether the individual has the necessary prerequisites for the relevant learning activity (Arık 1995; Yenilmez and Kakmaci 2008). For students who do not have prerequisites, education should be planned that is concrete, uncomplicated, and close to their previous experience. In the proposed material suggestion system, the level of readiness of the student for each course subject is determined and appropriate educational material is suggested. Questions prepared by the educator should be used to determine the level of readiness. In the proposed model, linguistic expressions of Very Ready (VR), Ready (R), Moderate (M), Not Ready (NR) and Never Ready (NVR) were used for readiness. The membership function graph for readiness is given in Figure 3.

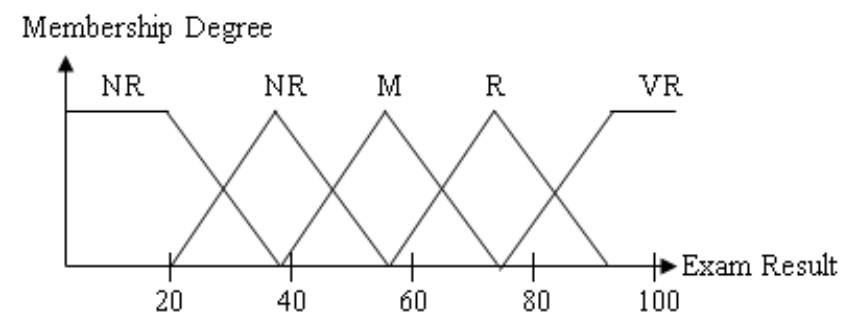

Figure 3. Membership function for readiness

\section{A Material Recommendation Model}

In the proposed model, a student-centered approach is used. The course materials to be presented to the students are determined according to their learning style, readiness level and material properties. The diagram of the proposed model is given in Figure 4.

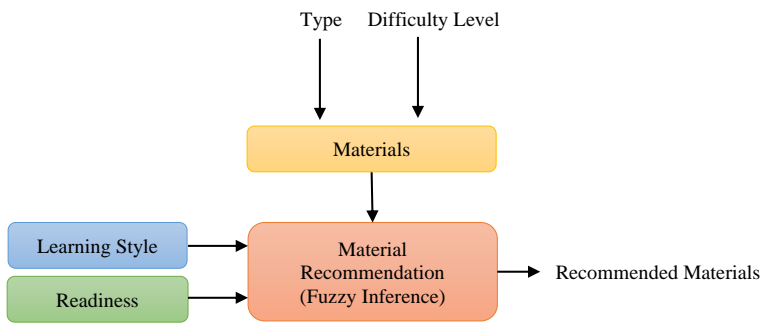

Figure 4. Suggested Material Recommendation Model

The proposed model works based on fuzzy inference and as input material difficulty level (VE-very easy, E-easy, M- 
moderate, D-difficult, VD-very difficult), type of material (Wwritten, IG-image and graphic, V-video, IA-interactive animation), learning style (IT, EX, IM, RF, AL, TH, DC, AC, BL) and readiness (VR-very ready, R-ready, M-moderate, NR-not ready and NVR-never ready) information. True and false values are used as output. If the relevant material is suitable for the student, true (1), otherwise false (0) will be output. The nine items in the learning style are the fuzzy versions of the four items (active experimentation, concrete experience, reflective observation, abstract conceptualization) based on the KLSI. Because the initiating learning style involves active practice and concrete experience. In line with this information, the rule table for the material recommendation is given in Table 2.

Table 2. Rule table for material recommendation

\begin{tabular}{|c|c|c|c|c|}
\hline $\mathbf{L S}$ & MT & RDN & MDL & Output \\
\hline$(\mathrm{IT}) \vee(\mathrm{IM})$ & $(\mathrm{IA}) \vee(\mathrm{V})$ & (VR) & $(\mathrm{VD}) \vee(\mathrm{D}) \vee(\mathrm{M}) \vee(\mathrm{E}) \vee(\mathrm{VE})$ & 1 \\
\hline$(\mathrm{IT}) \vee(\mathrm{IM})$ & $(\mathrm{IA}) \vee(\mathrm{V})$ & (R) & (VD) & 0 \\
\hline$(\mathrm{IT}) \vee(\mathrm{IM})$ & $(\mathrm{IA}) \vee(\mathrm{V})$ & (R) & $(\mathrm{D}) \vee(\mathrm{M}) \vee(\mathrm{E}) \vee(\mathrm{VE})$ & 1 \\
\hline$(\mathrm{IT}) \vee(\mathrm{IM})$ & $(\mathrm{IA}) \vee(\mathrm{V})$ & $(\mathrm{M})$ & $(\mathrm{VD}) \vee(\mathrm{D})$ & 0 \\
\hline$(\mathrm{IT}) \vee(\mathrm{IM})$ & $(\mathrm{IA}) \vee(\mathrm{V})$ & $(\mathrm{M})$ & $(\mathrm{M}) \vee(\mathrm{E}) \vee(\mathrm{VE})$ & 1 \\
\hline$(\mathrm{IT}) \vee(\mathrm{IM})$ & $(\mathrm{IA}) \vee(\mathrm{V})$ & (NR) & $(\mathrm{VD}) \vee(\mathrm{D}) \vee(\mathrm{M})$ & 0 \\
\hline$(\mathrm{IT}) \vee(\mathrm{IM})$ & $(\mathrm{IA}) \vee(\mathrm{V})$ & $(\mathrm{NR})$ & $(\mathrm{E}) \vee(\mathrm{VE})$ & 1 \\
\hline$(\mathrm{IT}) \vee(\mathrm{IM})$ & $(\mathrm{IA}) \vee(\mathrm{V})$ & (NVR) & $(\mathrm{VD}) \vee(\mathrm{D}) \vee(\mathrm{M}) \vee(\mathrm{E}) \vee(\mathrm{VE})$ & 0 \\
\hline$(\mathrm{IT}) \vee(\mathrm{IM})$ & $(\mathrm{W}) \vee(\mathrm{IG})$ & $(\mathrm{VR}) \vee(\mathrm{R}) \vee(\mathrm{M}) \vee(\mathrm{NR}) \vee(\mathrm{NVR})$ & $(\mathrm{VD}) \vee(\mathrm{D}) \vee(\mathrm{M}) \vee(\mathrm{E}) \vee(\mathrm{VE})$ & 0 \\
\hline$(\mathrm{EX}) \vee(\mathrm{TH})$ & $(\mathrm{EA}) \vee(\mathrm{V}) \vee(\mathrm{W})$ & (VR) & $(\mathrm{VD}) \vee(\mathrm{D}) \vee(\mathrm{M}) \vee(\mathrm{E}) \vee(\mathrm{VE})$ & 1 \\
\hline$(\mathrm{EX}) \vee(\mathrm{TH})$ & $(\mathrm{IA}) \vee(\mathrm{V}) \vee(\mathrm{W})$ & (R) & (VD) & 0 \\
\hline$(\mathrm{EX}) \vee(\mathrm{TH})$ & $(\mathrm{IA}) \vee(\mathrm{V}) \vee(\mathrm{W})$ & (R) & $(\mathrm{D}) \vee(\mathrm{M}) \vee(\mathrm{E}) \vee(\mathrm{VE})$ & 1 \\
\hline$(\mathrm{EX}) \vee(\mathrm{TH})$ & $(\mathrm{IA}) \vee(\mathrm{V}) \vee(\mathrm{W})$ & (M) & $(\mathrm{VD}) \vee(\mathrm{D})$ & 0 \\
\hline$(\mathrm{EX}) \vee(\mathrm{TH})$ & $(\mathrm{IA}) \vee(\mathrm{V}) \vee(\mathrm{W})$ & $(\mathrm{M})$ & $(\mathrm{M}) \vee(\mathrm{E}) \vee(\mathrm{VE})$ & 1 \\
\hline$(\mathrm{EX}) \vee(\mathrm{TH})$ & $(\mathrm{IA}) \vee(\mathrm{V}) \vee(\mathrm{W})$ & (NR) & $(\mathrm{VD}) \vee(\mathrm{D}) \vee(\mathrm{M})$ & 0 \\
\hline$(\mathrm{EX}) \vee(\mathrm{TH})$ & $(\mathrm{IA}) \vee(\mathrm{V}) \vee(\mathrm{W})$ & $(\mathrm{NR})$ & $(\mathrm{K}) \vee(\mathrm{VE})$ & 1 \\
\hline$(\mathrm{EX}) \vee(\mathrm{TH})$ & $(\mathrm{IA}) \vee(\mathrm{V}) \vee(\mathrm{W})$ & (NVR) & $(\mathrm{VD}) \vee(\mathrm{D}) \vee(\mathrm{M}) \vee(\mathrm{E}) \vee(\mathrm{VE})$ & 0 \\
\hline$(\mathrm{EX}) \vee(\mathrm{TH})$ & (IG) & $(\mathrm{VR}) \vee(\mathrm{R}) \vee(\mathrm{M}) \vee(\mathrm{NR}) \vee(\mathrm{NVR})$ & $(\mathrm{VD}) \vee(\mathrm{D}) \vee(\mathrm{M}) \vee(\mathrm{E}) \vee(\mathrm{VE})$ & 0 \\
\hline$(\mathrm{RF}) \vee(\mathrm{AL})$ & $(\mathrm{W}) \vee(\mathrm{V}) \vee(\mathrm{IG})$ & (VR) & $(\mathrm{VD}) \vee(\mathrm{D}) \vee(\mathrm{M}) \vee(\mathrm{E}) \vee(\mathrm{VE})$ & 1 \\
\hline$(\mathrm{RF}) \vee(\mathrm{AL})$ & $(\mathrm{W}) \vee(\mathrm{V}) \vee(\mathrm{IG})$ & (R) & (VD) & 0 \\
\hline$(\mathrm{RF}) \vee(\mathrm{AL})$ & $(\mathrm{W}) \vee(\mathrm{V}) \vee(\mathrm{IG})$ & (R) & (D) $\vee(M) \vee(E) \vee(V E)$ & 1 \\
\hline$(\mathrm{RF}) \vee(\mathrm{AL})$ & $(\mathrm{W}) \vee(\mathrm{V}) \vee(\mathrm{IG})$ & (M) & $(\mathrm{VD}) \vee(\mathrm{D})$ & 0 \\
\hline$(\mathrm{RF}) \vee(\mathrm{AL})$ & $(\mathrm{W}) \vee(\mathrm{V}) \vee(\mathrm{IG})$ & $(\mathrm{M})$ & $(\mathrm{M}) \vee(\mathrm{E}) \vee(\mathrm{VE})$ & 1 \\
\hline$(\mathrm{RF}) \vee(\mathrm{AL})$ & $(\mathrm{W}) \vee(\mathrm{V}) \vee(\mathrm{IG})$ & $(\mathrm{NR})$ & $(\mathrm{VD}) \vee(\mathrm{D}) \vee(\mathrm{M})$ & 0 \\
\hline$(\mathrm{RF}) \vee(\mathrm{AL})$ & $(\mathrm{W}) \vee(\mathrm{V}) \vee(\mathrm{IG})$ & (NR) & $(\mathrm{E}) \vee(\mathrm{VE})$ & 1 \\
\hline$(\mathrm{RF}) \vee(\mathrm{AL})$ & $(\mathrm{W}) \vee(\mathrm{V}) \vee(\mathrm{IG})$ & (NVR) & $(\mathrm{VD}) \vee(\mathrm{D}) \vee(\mathrm{M}) \vee(\mathrm{E}) \vee(\mathrm{VE})$ & 0 \\
\hline$(\mathrm{RF}) \vee(\mathrm{AL})$ & (IA) & $(\mathrm{VR}) \vee(\mathrm{R}) \vee(\mathrm{M}) \vee(\mathrm{NR}) \vee(\mathrm{NVR})$ & $(\mathrm{VD}) \vee(\mathrm{D}) \vee(\mathrm{M}) \vee(\mathrm{E}) \vee(\mathrm{VE})$ & 0 \\
\hline (DC) & $(\mathrm{IA}) \vee(\mathrm{W})$ & $(\mathrm{VR})$ & $(\mathrm{VD}) \vee(\mathrm{D}) \vee(\mathrm{M}) \vee(\mathrm{E}) \vee(\mathrm{VE})$ & 1 \\
\hline (DC) & $(\mathrm{IA}) \vee(\mathrm{W})$ & (R) & $(\mathrm{VD})$ & 0 \\
\hline (DC) & $(\mathrm{IA}) \vee(\mathrm{W})$ & $(\mathrm{R})$ & $(\mathrm{D}) \vee(\mathrm{M}) \vee(\mathrm{E}) \vee(\mathrm{VE})$ & 1 \\
\hline (DC) & $(\mathrm{IA}) \vee(\mathrm{W})$ & (M) & $(\mathrm{VD}) \vee(\mathrm{D})$ & 0 \\
\hline (DC) & $(\mathrm{IA}) \vee(\mathrm{W})$ & (M) & $(\mathrm{M}) \vee(\mathrm{E}) \vee(\mathrm{VE})$ & 1 \\
\hline (DC) & $(\mathrm{IA}) \vee(\mathrm{W})$ & (NR) & $(\mathrm{VD}) \vee(\mathrm{D}) \vee(\mathrm{M})$ & 0 \\
\hline (DC) & $(\mathrm{IA}) \vee(\mathrm{W})$ & $(\mathrm{NR})$ & $(\mathrm{E}) \vee(\mathrm{VE})$ & 1 \\
\hline (DC) & $(\mathrm{IA}) \vee(\mathrm{W})$ & (NVR) & $(\mathrm{VD}) \vee(\mathrm{D}) \vee(\mathrm{M}) \vee(\mathrm{E}) \vee(\mathrm{VE})$ & 0 \\
\hline (DC) & $(\mathrm{V}) \vee(\mathrm{IG})$ & $(\mathrm{VR}) \vee(\mathrm{R}) \vee(\mathrm{M}) \vee(\mathrm{NR}) \vee(\mathrm{NVR})$ & $(\mathrm{VD}) \vee(\mathrm{D}) \vee(\mathrm{M}) \vee(\mathrm{E}) \vee(\mathrm{VE})$ & 0 \\
\hline$(\mathrm{AC})$ & $(\mathrm{IA}) \vee(\mathrm{W}) \vee(\mathrm{IG})$ & $(\mathrm{VR})$ & $(\mathrm{VD}) \vee(\mathrm{D}) \vee(\mathrm{M}) \vee(\mathrm{E}) \vee(\mathrm{VE})$ & 1 \\
\hline$(\mathrm{AC})$ & $(\mathrm{IA}) \vee(\mathrm{W}) \vee(\mathrm{IG})$ & (R) & (VD) & 0 \\
\hline (AC) & $(\mathrm{IA}) \vee(\mathrm{W}) \vee(\mathrm{IG})$ & (R) & (D) $\vee(M) \vee(E) \vee(V E)$ & 1 \\
\hline$(\mathrm{AC})$ & $(\mathrm{IA}) \vee(\mathrm{W}) \vee(\mathrm{IG})$ & (M) & $(\mathrm{VD}) \vee(\mathrm{D})$ & 0 \\
\hline$(\mathrm{AC})$ & $(\mathrm{IA}) \vee(\mathrm{W}) \vee(\mathrm{IG})$ & (M) & $(\mathrm{M}) \vee(\mathrm{E}) \vee(\mathrm{VE})$ & 1 \\
\hline$(\mathrm{AC})$ & $(\mathrm{IA}) \vee(\mathrm{W}) \vee(\mathrm{IG})$ & $(\mathrm{NR})$ & $(\mathrm{VD}) \vee(\mathrm{D}) \vee(\mathrm{M})$ & 0 \\
\hline$(\mathrm{AC})$ & $(\mathrm{IA}) \vee(\mathrm{W}) \vee(\mathrm{IG})$ & $(\mathrm{NR})$ & $(\mathrm{E}) \vee(\mathrm{VE})$ & 1 \\
\hline$(\mathrm{AC})$ & $(\mathrm{IA}) \vee(\mathrm{W}) \vee(\mathrm{IG})$ & (NVR) & $(\mathrm{VD}) \vee(\mathrm{D}) \vee(\mathrm{M}) \vee(\mathrm{E}) \vee(\mathrm{VE})$ & 0 \\
\hline$(\mathrm{AC})$ & $(\mathrm{V})$ & $(\mathrm{VR}) \vee(\mathrm{R}) \vee(\mathrm{M}) \vee(\mathrm{NR}) \vee(\mathrm{NVR})$ & $(\mathrm{VD}) \vee(\mathrm{D}) \vee(\mathrm{M}) \vee(\mathrm{E}) \vee(\mathrm{VE})$ & 0 \\
\hline$(\mathrm{BL})$ & $(\mathrm{IA}) \vee(\mathrm{W}) \vee(\mathrm{V}) \vee(\mathrm{IG})$ & (VR) & $(\mathrm{VD}) \vee(\mathrm{D}) \vee(\mathrm{M}) \vee(\mathrm{E}) \vee(\mathrm{VE})$ & 1 \\
\hline (BL) & $(\mathrm{IA}) \vee(\mathrm{W}) \vee(\mathrm{V}) \vee(\mathrm{IG})$ & (R) & (VD) & 0 \\
\hline (BL) & $(\mathrm{IA}) \vee(\mathrm{W}) \vee(\mathrm{V}) \vee(\mathrm{IG})$ & (R) & $(\mathrm{D}) \vee(\mathrm{M}) \vee(\mathrm{E}) \vee(\mathrm{VE})$ & 1 \\
\hline$(\mathrm{BL})$ & $(\mathrm{IA}) \vee(\mathrm{W}) \vee(\mathrm{V}) \vee(\mathrm{IG})$ & $(\mathrm{M})$ & $(\mathrm{VD}) \vee(\mathrm{D})$ & 0 \\
\hline (BL) & $(\mathrm{IA}) \vee(\mathrm{W}) \vee(\mathrm{V}) \vee(\mathrm{IG})$ & $(\mathrm{M})$ & $(\mathrm{M}) \vee(\mathrm{E}) \vee(\mathrm{VE})$ & 1 \\
\hline (BL) & $(\mathrm{IA}) \vee(\mathrm{W}) \vee(\mathrm{V}) \vee(\mathrm{IG})$ & (NR) & $(\mathrm{VD}) \vee(\mathrm{D}) \vee(\mathrm{M})$ & 0 \\
\hline (BL) & $(\mathrm{IA}) \vee(\mathrm{W}) \vee(\mathrm{V}) \vee(\mathrm{IG})$ & (NR) & $(\mathrm{E}) \vee(\mathrm{VE})$ & 1 \\
\hline (BL) & $(\mathrm{IA}) \vee(\mathrm{W}) \vee(\mathrm{V}) \vee(\mathrm{IG})$ & (NVR) & $(\mathrm{VD}) \vee(\mathrm{D}) \vee(\mathrm{M}) \vee(\mathrm{E}) \vee(\mathrm{VE})$ & 0 \\
\hline
\end{tabular}

MDL: Material difficulty level, MT: Materyal type, LS: Learning style, RDN: Readiness 
When the rules in Table 2 are examined, a few examples of comments that can be made are given below.

- Materials in the form of interactive animations and written documents are recommended for a student with a decision-making learning style, if the readiness for the lesson is very ready, regardless of the difficulty level of the material. In addition, if the readiness of this student is not considered, video and picture materials are not recommended.

- For a student with a balancing learning style, if the readiness for the lesson is very ready, any material can be recommended regardless of the difficulty level of the material and the type of material.

- Video-type material is not recommended for a student with an acting learning style, regardless of their readiness for the lesson and the difficulty level of the material.

\section{Conclusion and Discussion}

Distance learning platforms facilitate interaction between students and instructors while reducing temporal or spatial constraints. However, such platforms require measuring the degree of student engagement in the delivered course content and teaching style. Such information is invaluable for assessing the quality of teaching and changing the style of teaching delivery in mass online learning platforms. In addition, since the learning process will continue individually, appropriate course materials should be presented to the students. The materials are presented to the students through the student's inquiries on the system or the predictions based on the student's past records. This is a situation in which the student's cognitive and affective competences are not actively used.

The learning theory developed by Kolb focuses on both cognitive and affective dimensions as well as emphasizing the importance of experiences in the learning process (Can 2011). Therefore, the materials to be presented to students should be determined according to the learning style of the student. The use of only learning style for material recommendation is still insufficient for the student. Because the material to be proposed to the student should be suitable for the level of the student. With readiness, it is investigated whether the student has sufficient knowledge for the new subject to be learned. In short, readiness is whether the individual has the necessary prerequisites for the relevant learning activity (Arik 1995; Yenilmez and Kakmac1 2008). The materials to be presented to the students should be planned in parallel with the learning style. Therefore, the type and difficulty level for the materials also strengthen the studentcentered approach.

Within the scope of this information, in this study, a material recommendation system, which aims a student-centered approach for distance learning systems, is modeled. The proposed model uses learning style, readiness level, material type and difficulty level as inputs for the fuzzy inference system. As an output, it is determined whether the relevant material is suitable for the student or not. To determine the learning style, the student's demographic data, KLSI 4.0 result, time spent for KLSI 4.0 in this process and emotion were used. It is suggested to use level determination exams prepared by the trainer for readiness. After the fuzzy logic-based model was created, the rule table was created and given in Table 2 .
The biggest limitation seen in the study is the increase in the workload of the educator. However, once the proposed model is created, it can be used in the distance learning system for many years. Another limitation is that students give unrealistic answers to KLSI in the process of determining the learning style. It has been suggested to use time and emotion to avoid this limitation. However, this will not be the definitive solution.

In future studies, materials from different courses can be presented together, according to the student's interests, by applying association rules while making material proposals.

\section{References}

Akengin, Hamza, and Sevgi Süer. 2013. 'An Experimental Research on Readiness Levels of Students in Terms of Geographical Concepts and Development of These Concepts'. Marmara Geographical Review (24):26-48.

Altun, Murat. 2005. Matematik Öğretimi. 4. Basım. Bursa: Aktüel Yayınlar1.

Anon. 2017. 'Kolb Öğrenme Stilleri - DeM'. Retrieved 16 June $2021 \quad$ (https://www.demturkey.com/deneyimselogrenme/kolb-ogrenme-stilleri/).

Arık, İ. Alev. 1995. Öğrenme Psikolojisine Giriş. İstanbul: Der Yaya.

Aşkar, Petek, and Buket Akkoyunlu. 1993. 'Kolb Öğrenme Stili Envanteri'. Eğitim ve Bilim 17(87).

Bahar, Hüseyin Hüsnü, and Ali Sülün. 2011. 'Learning styles of science teacher candidates, the link between gender and Learning styles, according to learning styles Of academic success'. Kastamonu Education Journal 19(2):379-86.

Can, Şendil. 2011. 'Investigation of the relationships between the learning styles of preservice elementary teachers and some variables'. H.U Journal of Education 41:70-82.

Cevher, Ahmet Yusuf, and Serkan Yıldırım. 2020. Investigation of Academic Studies on Learning Styles: A Systematic Review'. Hayef: Journal of Education (Online) 17(1):20-50.

Chen, Wei, Zhendong Niu, Xiangyu Zhao, and Yi Li. 2014. 'A Hybrid Recommendation Algorithm Adapted in E-Learning Environments'. World Wide Web 17(2):271-84.

Çöpgeven, Selin, and Mehmet Frrat. 2019. 'Uzaktan Eğitimde Algoritmalar: 2007-2019 Sistematik Alanyazın Taraması'. Açıö̆gretim Uygulamaları ve Araştırmaları Dergisi, 5(4): 65-91.

El Aissaoui, Ouafae, Yasser El Alami El Madani, Lahcen Oughdir, and Youssouf El Allioui. 2019. 'A Fuzzy Classification Approach for Learning Style Prediction Based on Web Mining Technique in E-Learning Environments'. Education and Information Technologies 24(3):1943-59.

Erdoğan, Özdemir Emel, Abdükadir Erdoğan, and Sezgin Çelik. 2012. 'First Year Prospective Middle School Mathematics Teachers Readiness for Functions'. Gaziantep University Journal of Social Sciences 11(4): 1121-1149.

Fraley, Mary A., A. J. Hamlin, Amber Kemppainen, and Gretchen L. Hein. 2015. 'Using Pre-Lesson Materials and Quizzes to Improve Student Readiness and Performance'. P. 26.1677.126.1677.16 in.

Given, Barbara K. 1996. 'Learning Styles: A Synthesized Model'. Journal of Accelerative Learning and Teaching 21:9-42.

Gökbulut, Bayram. 2021. 'Distance education and mobile learning from the perspective of distance education students'. Educational Technology Theory and Practice 11(1):160-77. 
Göldağ, B. 2011. ‘Öğrenme Stili Öğretmenlerininki İle Aynı Olan ve Olmayan Öğrencilerin Akademik Başarılarının İncelenmesi’. Eğitim Bilimleri Kurultayı 8-10.

İnan, Cemil. 2014. 'Evaluation of Pre-School Teacher Candidates' Levels of Readiness for Teaching Mathematics.' Electronic Turkish Studies 9(8): 537-550.

Kartal, Elif, Sezer Köse Biber, Mahir Biber, Melodi Ozyaprak, İrfan Şimşek, and Tuncer Can. 2019. 'A Model Proposal to Determine Learning Styles of Students by Using Machine Learning Techniques and Kolb Learning Styles Inventory'. Kastamonu Ĕ̈itim Dergisi 27(5):1875-92.

Kolb, A. Y. 2013. 'The Kolb Learning Style Inventory-Version 4.0. a Comprehensive Guide to the Theory, Psychometrics, Research on Validity and Educational Applications'. Kaunakakai, HI: Experience Based Learning Systems.

Kolb, Alice Y. 2013. 'The Kolb Learning Style Inventory 4.0: A Comprehensive Guide to the Theory, Psychometrics, Research on Validity and Educational Applications'. Philadelphia, PA: Hay Group.

Kolb, David A. 1985. Learning-Style Inventory: Self-Scoring Inventory and Interpretation Booklet. TRG Hay/McBer.

Koloğlu, Tevfik Fikret, Mahmut Kantar, and Mevlüt Doğan. 2016. 'Öğretim elemanlarının uzaktan eğitimde hazırbulunuşluklarının önemi'. Açıköğretim Uygulamaları ve Araştırmaları Dergisi 2(1):52-70.

Liu, Feng-jung, and Bai-jiun Shih. 2007. 'E-Learning ActivityBased Material Recommendation System'. Interactive Technology and Smart Education.

Lu, Jie. 2004. 'A Personalized E-Learning Material Recommender System'. in International Conference on Information Technology and Applications. Macquarie Scientific Publishing.

Menaka, P., and K. Nandhini. 2019. 'Performance of Data Mining Classifiers on Kolb's Learning Style Inventory (KLSI)'. Indian Journal of Science and Technology 12:23.

Pandey, Himanshu, and V. K. Singh. 2015. 'A Fuzzy Logic Based Recommender System for E-Learning System with MultiAgent Framework'. International Journal of Computer Applications 122(17):18-21.

Perumal, Sankar Pariserum, Ganapathy Sannasi, and Kannan Arputharaj. 2019. 'An Intelligent Fuzzy Rule-Based eLearning Recommendation System for Dynamic User Interests'. The Journal of Supercomputing 75(8):5145-60.

Rasheed, Fareeha, and Abdul Wahid. 2021. 'Learning Style Detection in E-Learning Systems Using Machine Learning Techniques'. Expert Systems with Applications 174:114774.

Salehi, Mojtaba, and Isa Nakhai Kmalabadi. 2012. 'A Hybrid Attribute-Based Recommender System for e-Learning Material Recommendation'. Ieri Procedia 2:565-70.

Sanjabi, Tahereh, and Gholam Ali Montazer. 2020. 'Personalization of E-Learning Environment Using the Kolb's Learning Style Model'. Pp. 89-92 in 2020 6th International Conference on Web Research (ICWR). IEEE.

Syed, Thoufeeq Ahmed, Vasile Palade, Rahat Iqbal, and Smitha Sunil Kumaran Nair. 2017. 'A Personalized Learning Recommendation System Architecture for Learning Management System.' Pp. 275-82 in KDIR.

Trusthi, Swapaka Listya, and Dade Nurjanah. 2017. 'Combination of Hybrid Filtering and Learning Style for Learning Material Recommendation'. Pp. 24-29 in 2017 IEEE Conference on e-Learning, e-Management and $e$ Services (IC3e). IEEE.
Tuna, Abdulkadir, and Ahmet Kaçar. 2005. 'The level of the readiness of students who begun primary school mathematics teaching programme related to high school 2 mathematics subjects'. Kastamonu Education Journal. 13(1):117-128.

Turnip, Rudolf, Dade Nurjanah, and Dana Sulistyo Kusumo. 2017. 'Hybrid Recommender System for Learning Material Using Content-Based Filtering and Collaborative Filtering with Good Learners' Rating'. Pp. 61-66 in 2017 IEEE Conference on e-Learning, e-Management and e-Services $(I C 3 e)$. IEEE.

Ünal, Menderes, and Çağatay Özdemir. 2008. 'The Effect of Cognitive Readiness on The Academic Success of The Students Taking Foreign Language Courses at Faculties of Education'. Ahi Evran Üniversitesi Kırşehir Eğitim Fakültesi Dergisi 9(1):13-22.

Unutkan, Özgül Polat. 2007. ‘A study of pre- school children's school readiness related to skills of mathematics'. H.U Journal of Education 32(32):243-54.

Yenilmez, Kürşat, and Özlem Kakmac1. 2008. 'The level of the readiness of seventh grade Students in mathematics'. Kastamonu Education Journal 16(2):529-42. 